\title{
AGGRESSIVE PERIPHERAL GIANT CELL GRANULOMA IN POSTERIOR MANDIBLE-CASE REPORT IN A CHILD
}

\section{ABSTRACT}

The peripheral giant cell granuloma (PGCG) is a common benign hyperplastic and reactive gingival lesion occurring mostly in adults. We report a case of a 10-year-old boy presenting with a six-month history soft tissue mass of the left mandibular gingiva associated with ulceration area. An excisional biopsy of the lesion followed by histopathologic examination of the biopsy specimen revealed distinctive features of peripheral giant cell granuloma. In these case report after 12 months of follow up spontaenous eruptions of permanent teeth were noticed. Clinical, radiographical and histological characteristics are discussed and recommendations regarding treatment.

Key Words:Giant Cell Granuloma, Pediatric Dentistry, children

\author{
Arife Kaptan ${ }^{1}$ \\ (D) Çiğdem Çukurcu ${ }^{1}$ \\ (ID)Turan Emre Kuzu²
}

ORCID IDs of the authors:

A.K. 0000-0003-4371-7768

Ç.Ç. $0000-0001-7308-8750$

T.E.K. 0000-0002-9478-1578

${ }^{1}$ Cumhuriyet University, Faculty of Dentistry, Department of Pediatric Dentistry, Sivas, Turkey

${ }^{2}$ Nuh Naci Yazgan University, Faculty of Dentistry, Department of Periodontology, Kayseri, Turkey

$\begin{array}{ll}\text { Received }: 11.02 .2019 \\ \text { Accepted } & : 07.03 .2019\end{array}$ 


\section{INTRODUCTION}

Solitary gingival enlargements in children are relatively common and usually occur in reaction to local irritation or chronic trauma. One of these enlargements is peripheral giant cell granuloma (PGCG), a lesion unique to the oral cavity, occurring only on the gingiva. ${ }^{1}$

Peripheral giant cell granuloma (PGCG) is an oral, non-neoplastic, tumor-like growth that occurs exclusively on the gingiva and the alveolar mucosa. It is never found on non-osseous supported tissues. ${ }^{2,3}$ This lesion has been reported to account for $5.1 \%$ to $43.6 \%$ of reactive gingival overgrowths. ${ }^{2,4-9}$ It affects both sexes, with a slight predilection for females especially after puberty. Although peak prevalence is found in the fifth and sixth decades of life, 20 to $30 \%$ of cases occur within the first two decades of life. The most common location of the PGCG is the incisor and canine regions with a slight predilection for the mandible. ${ }^{3,6,7}$

The etiology of this lesion is not completely understood. However, local irritating factors such as teeth extraction, ill-fitting prostheses, poor restorations, collections of food remnants and calculus, seem to play an important role in the development of these lesions. ${ }^{10,11}$

PGCG are derived from periosteum and periodontal ligament and occurs frequently in young adults. It occurs in variable sizes, sessile or pedunculated. ${ }^{2}$ PGCG appear as a reddish purple or purplish blue lump with smooth shiny or papillomatous surface. It is a well-defined lesion with exophytic growth and rarely exceeds $3 \mathrm{~cm}$ in their greater dimension. ${ }^{12}$

It is distinguishable from similar lesion only on the basis of its unique histomorphology, which is essentially identical to that of central giant cell granuloma, intrabony benign neoplasm of the jawbone. ${ }^{1}$

Our study is aimed to report a case of aggressive PGCG in a young child which was misdiagnosed and neglected for more than 6 months.

\section{CASE REPORT}

A healthy 10-year-old boy was referred for evaluation of a gingival mass on the left mandibular canine-premolar region that was first observed six months prior to examination. A clinical examination was performed after obtaining the required consent form from the patient's parent. The lesion was interfering with normal permanent premolars eruption. The medical history did not reveal any unusual findings. The patient reported that the lesion first appeared 6 months ago, after primary tooth caries and fractures. Clinical examination revealed that the lower permanent left canine and premolars were absent, and presence of retained primary second molar tooth residues with a reddish-purple, sessile nodule, of approximately $7 \mathrm{~mm}$ in diameter. The surface was smooth, except for local areas of ulceration (Figure 1).



Fig 1. Intraoral preoperative view of lesion

The lesion was painless and with no associated spontaneous bleeding except for occasional interference of the swelling with mastication. A panoramic radiograph of the site demonstrates destruction of the alveolar bone and migration of permanent canine and premolar germs. (Figure 2). No other oral or cutaneous lesions were noted in this healthy child.

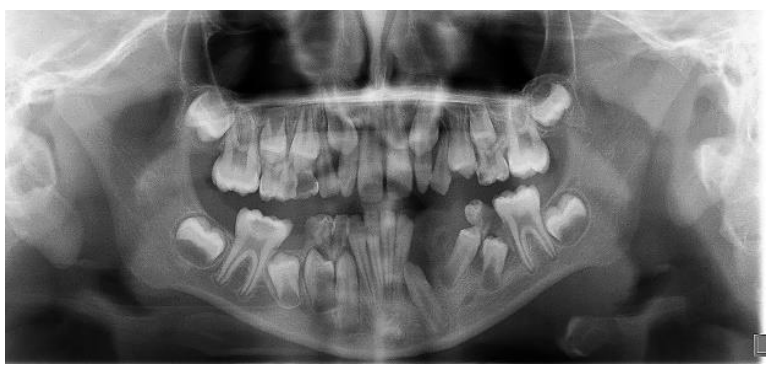

Fig 2. Panoromic radiograph showing destruction of the alveolar bone and migration of permanent toooth

\section{TREATMENT}

Oral hygiene instructions were given to the patient, and oral prophylaxis was done. After one week, 
under local anaesthesia, the mass was excised with retained tooth residues and submitted for histological examination with a preoperative diagnosis of reactive hyperplasia. Patient was motivated and educated to maintain his oral hygiene.

Histopathological examination of the specimen revealed an ulcerated giant cell granuloma characterized by the proliferation of elongated fibroblastic cells with ovoid nuclei lacking atypia or mitosis and by the diffuse infiltration of osteoclast-like multinucleated giant cells in a fibrous connective tissue. The connective tissue exhibited multinucleated giant cells dispersed throughout a fibrovascular stroma. Histologically, the specimen was suggestive of PGCG. Based on the clinical and histological findings, the lesion was diagnosed as PGCG.

After surgical procedure, healing was uneventful, and no recurrence was observed after 12 months follow-up. During this period the patient did not report any complaints. Tooth eruption was observed in clinical and radiograph examinations, and no other treatment was needed (Figures 3 and 4).

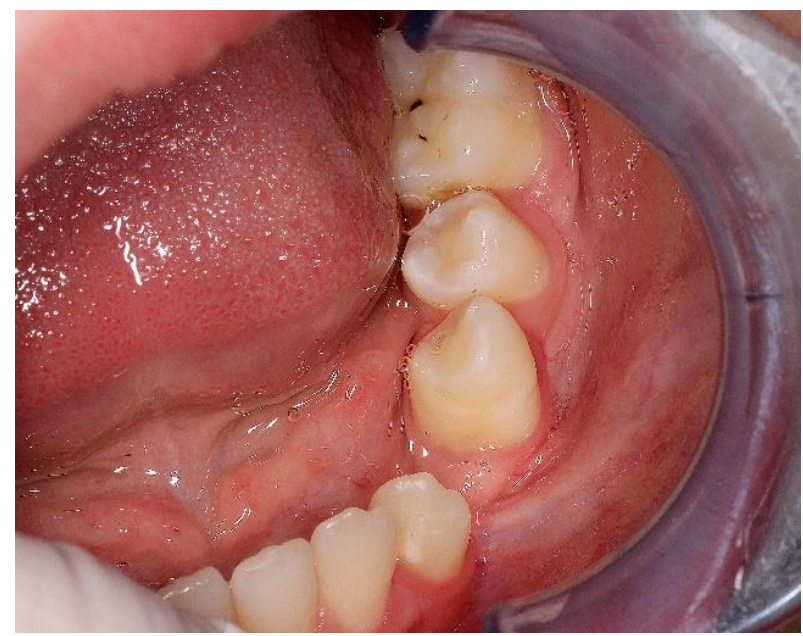

Fig 3. Clinical follow-up 12 months after surgical excision showing the permanent erupted tooth and no recurrence of the lesion

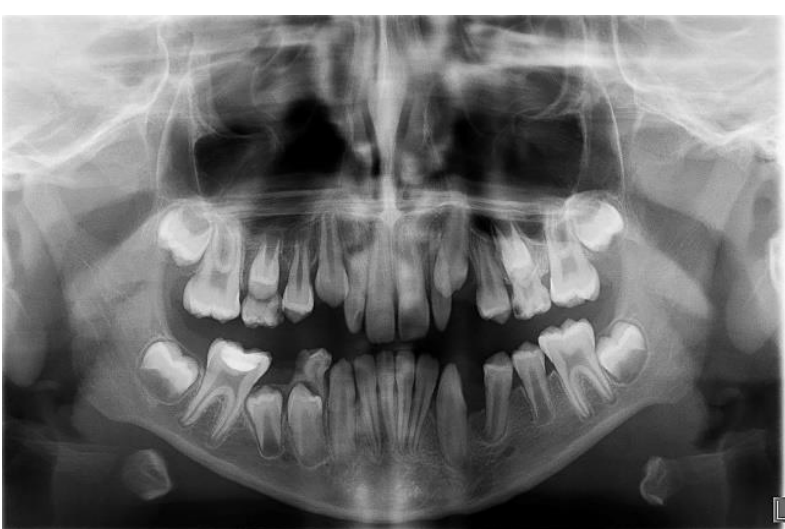

Fig 4. Follow-up 12 months after surgical excision

DISCUSSION

In children, single gingival enlargements are relatively a common finding and are usually the result of a reactive response to local irritation. These lesions may grow rapidly and reach a significant size within several months of its initial diagnosis. ${ }^{4,7,13,14}$ PGCG is more common in fifth and sixth decades of life than in children and the pyogenic granuloma is the most common reactive lesion in children. ${ }^{3,7,13}$ In a review of 720 cases, $33 \%$ were seen in patients younger than 20 years of age, which concurs with the findings of another study in which 33 of 97 cases (34\%) occurred in individuals between 5 and 15 years of age. ${ }^{2,15}$ The most common location for the PGCG is the incisor and canine regions, with a slight predilection for the mandible. ${ }^{3}$ In this paper we reported a case of PGCG located on mandible premolar region in an 10-year-old boy.

Peripheral giant cell granuloma can behave very aggressively, especially in children. The criteria used to define aggressiveness of a PGCG are its size, the extension of the lesion in neighbouring tissues, its ability to relapse, the associated bone resorption, bone displacements, interfere with eruption of adjacent teeth, minor to moderate tooth movement, and have multiple recurrences. ${ }^{16,17}$

The aetiology of PGCG is unknown but local irritation factors such as poor dental restorations, unstable dental prosthesis, dental extractions, plaque and calculus accumulation, food retention seem to play an important role in the development of PGCG. ${ }^{3,4,7}$ In the case we describe, the identifiable trigger is neglected decayed primary tooth and accordingly retained tooth residues. 
Clinically, PGCG presents as a firm, soft, bright pedunculated or sessile nodule with various sizes that range from small papules to enlarged masses, though they are generally less than $20 \mathrm{~mm}$ in diameter with the color ranging from dark red to purple or blue commonly with ulcerated surface., Pain is not a common characteristic, and in most cases lesion growth is induced by repeated trauma. ${ }^{1}$ In this case, we present a reddish-purple, sessile nodule, of approximately $7 \mathrm{~mm}$ in diameter and the lesion was painless and with no associated spontaneous bleeding.

Microscopically, PGCG is often ulcerated or eroded. The underlying connective tissue consists of fibroblast and multinucleated osteoclast-like giant cells. Extravasated red cells and deposits of haemosiderin, which are responsible for the classic brown-reddish colour of the PGCG are often present. Inflammatory cells and bone (woven and/or metaplastic) are found in about one-third of the cases. ${ }^{18}$ The stroma may contain osteoblasts, myofibroblasts, macrophages, and Langerhans cells. Histopathologically, the differential diagnosis of the PGCG must be made primarily with the Central Giant Cell Granuloma (CGCG). ${ }^{19-21}$

In differential diagnosis in the cases of gingival enlargements in children we consider gingival lesions that mimic PGCG, like; peripheral ossifying fibroma, peripheral odontogenic fibroma, parulis, and hemangioma. The peripheral ossifying fibroma is a reactive gingival growth that shares similar clinical features as the PGCG. In radiological evaluation, the identification of small calcification spots in the lesion helps to diagnose peripheral ossifying fibroma. ${ }^{16}$ The pyogenic granuloma may be difficult to differentiate from the PGCG based on clinical features alone. In general the pyogenic granuloma presents as a soft, friable nodule that bleeds freely with minimal manipulation. Unlike the PGCG, displacement of teeth and resorption of alveolar bone are not observed. ${ }^{16}$ The PGCG is distinguishable from pyogenic granuloma and peripheral ossifying fibroma only on the basis of its unique histomorphology, which is the same as central giant cell granuloma., ${ }^{2,15}$ Another erythematous nodule of the gingiva is the parulis, which is associated with an stucked foreign body, a gingival pocket and/or a nonvital tooth. Pain and the expression of a purulent exudate with fluctuation in lesion size help to differentiate this inflammatory disease from the PGCG. ${ }^{16}$ The other consideration based on the red or blue discoloration of the soft tissue nodule is a hemangioma. Although many hemangiomas are congenital lesions, some vascular malformations increase in size during childhood. Brisk bleeding, increased warmth of the tissue and blanching upon palpation are characteristic of this vascular entity. ${ }^{16}$ Clinically, peripheral odontogenic fibroma must be considered in the differential diagnosis of domeshaped or nodular, nonulcerated, growths on the gingiva like PGCG. Peripheral odontogenic fibroma is characterized by a fibrous or fibromyxomatous stroma containing varying numbers of islands and strands of odontogenic epithelium which is clearly distinguishable from PGCG histopathology. ${ }^{6}$

Management of this gingival lesion includes surgical excision and elimination of any local provocative factors. ${ }^{14,21}$ Recurrences of the PGCG have been reported in 5\% to $70.6 \%$ of cases. This great variation is probably attributable to the surgical technique used, since recurrences reexcised up to the periosteum have not recurred thereafter. ${ }^{3,9}$

Although, multiple recurrences with eventual loss of the adjacent teeth are a potential complication. ${ }^{16}$ Early diagnosis based on clinical and radiological findings, confirmed by pathological analysis especially in children, allows for conservative management with less risk of destruction for the adjacent teeth and tissues. ${ }^{22}$

In rare cases, PGCG may be the sole expression of a hyperparathyroidism. Bergdhal ${ }^{23}$ showed that $1.9-6 \%$ of the patients with a gingival lesion with multinucleated cells also have hyperparathyroidism. A case of recurrent PCGC has also been described by Stratakis et al. ${ }^{24}$ in a 9year-old boy affected by X-linked hypophosphatemic rickets, a condition associated with subclinical hyperparathyroidism. In a patient with typical lesions suggesting PGCG, especially when multiple or reoccurring after treatment, 
hyperparathyroidism should hence be
excluded. ${ }^{19,25-27}$

\section{CONCLUSIONS}

Peripheral giant cell granuloma is a disease encountered often in the adult population. It is very rarely found in children and represents only a very small proportion of the hyperplasic gingival lesions. PGCG, as our case illustrates it, may well occur after a dental traumatism. Because of the potential local aggressive behaviour of this type of lesion, an early diagnosis and effective surgical management is warranted especially in children. Early diagnosis based on clinical and radiological findings and confirmed by pathological analysis allows for conservative management with less risk of destruction for the adjacent teeth and tissues.

\section{ACKNOWLEDGEMENTS}

None

\section{CONFLICTS OF INTEREST}

The authors declare no potential conflicts of interest with respect to the authorship and/or publication of this article.

\section{Posterior Mandibular Bölgede Agresif Periferal Dev Hücreli Granüloma - Bir Olgu Sunumu Öz}

Periferik dev hücreli granüloma (PGCG), çoğunlukla yetişkinlerde görülen yaygın, benign, hiperplastik ve reaktif dişsti lezyonudur. Bu çalı̧̧mada, ülserasyon bölgesi ile ilişkili sol mandibular dişsetinde altı ayldır bulunan yumuşak doku kitlesi ile başvuran 10 yaşında bir erkek hasta bildirildi. Lezyonun eksizyonel biyopsisi, ardından biyopsi örneğinin histopatolojik incelemesi, periferik dev hücreli granülomun ayırt edici özelliklerini ortaya çıkardl. Bu olgu sunumunda 12 aylk takip sonrasında daimi dişlerde spontane erüpsiyonlar gözlendi. Bu vaka sunumunda, klinik, radyografik ve histolojik özellikler tartışlmakta ve tedaviyle ilgili önerilerde bulunulmaktadır. Anahtar Kelimeler: Granülom, periferal dev hücre, çocuk diş hekimliği.

\section{REFERENCES}

1. Neville BW, Damm DD, Allen CM, Bouquot JE. Soft tissue tumors. In: Neville BW, Damm DD, Allen CM, Bouquot JE (eds). Oral and Maxillofacial Pathology. Philadelphia, USA: WB Saunders 2015: 485.

2. Giansanti J. Peripheral giant cell granuloma: review of 720 cases. J Oral Surg 1969;27:787-791.
3. Katsikeris N, Kakarantza-Angelopoulou E, Angelopoulos AP. Peripheral giant cell granuloma. Clinicopathologic study of 224 new cases and review of 956 reported cases. Int J Oral Maxillofac Surg 1988;17:94-99.

4. Anneroth G, Sigurdson Å. Hyperplastic lesions of the gingiva and alveolar mucosa: a study of 175 cases. Acta Odontol Scand 1983;41:75-86.

5. Bodner L, Peist M, Gatot A, Fliss DM. Growth potential of peripheral giant cell granuloma. Oral Surg Oral Med Oral Pathol Oral Radiol Endod 1997;83:548551.

6. Daley T, Wysocki G, Wysocki P, Wysocki D. The major epulides: clinicopathological correlations. J Can Dent Assoc 1990;56:627-630.

7. Kfir Y, Buchner A, Hansen LS. Reactive lesions of the gingiva: a clinicopathological study of 741 cases. J Periodontol 1980;51:655-661.

8. Macleod R, Soames J. Epulides: a clinicopathological study of a series of 200 consecutive lesions. Br Dent J 1987;163:51.

9. Mighetl A, Robinson P, Hume W. Peripheral giant cell granuloma: a clinical study of 77 cases from 62 patients, and literature review. Oral Dis 1995;1:12-19.

10. Bernier JL, Cahn LR. The peripheral giant cell reparative granuloma. J Am Dent Assoc 1954;49:141148.

11. Eversole L, Rovin S. Reactive lesions of the gingiva. J Oral Pathol Med 1972;1:30-38.

12. Ottoman BA. Peripheral Giant Cell Granuloma Reaching an Impressive Overgrowth: A Case Report. Open J Dent Oral Med 2015;3:91-93.

13. Breault L, Fowler E, Wolfgang M, Lewis D. Peripheral giant cell granuloma: a case report. Gen Dent 2000;48:716-719.

14. Eronat N, Aktug M, Giinbay T, Unal T. Peripheral giant cell granuloma: three case reports. J Clin Pediatr Dent 2000;24:245-248.

15. Andersen L, Fejerskov O, Philipsen HP. Oral giant cell granulomas a clinical and histological study of 129 new cases. Acta Pathol Microbiol Scand A 1973;81:606-616.

16. Flaitz CM. Peripheral giant cell granuloma: a potentially aggressive lesion in children. Pediatr Dent 2000;22:232-233.

17. Pandolfi P, Felefli S, Flaitz C, Johnson J. An aggressive peripheral giant cell granuloma in a child. $\mathrm{J}$ Clin Pediatr Dent 1999;23:353-355. 
18. Grand E, Burgener E, Samson J, Lombardi T. Posttraumatic development of a peripheral giant cell granuloma in a child. Dent Traumatol 2008;24:124-126. 19. Burkes EJ, White RP. A peripheral giant-cell granuloma manifestation of primary hyperparathyroidism: report of case. J Am Dent Assoc 1989;118:62-64.

20. Flanagan AM, Tinkler SM, Horton M, Williams D, Chambers T. The multinucleate cells in giant cell granulomas of the jaw are osteoclasts. Cancer 1988;62:1139-1145.

21. Lim L, Gibbins JR. Immunohistochemical and ultrastructural evidence of a modified microvasculature in the giant cell granuloma of the jaws. Oral Surg Oral Med Oral Pathol Oral Radiol Endod 1995;79:190-198.

22. Nekouei A, Eshghi A, Jafarnejadi P, Enshaei Z. A review and report of peripheral giant cell granuloma in a 4-year-old child. Case Rep Dent 2016;2016.

23. Bergdahl L. Giant cell lesion of the mandible in coincidental hyperparathyroidism and hyperthyroidism. Am Surg 1975;41:650-654.
24. Stratakis CA, Mitsiades NS, Sun D, Chrousos GP, O'Connell A. Recurring oral giant cell lesion in a child with X-linked hypophosphatemic rickets: Clinical manifestation of occult parathyroidism? J Pediatr 1995; 127:444-446.

25. Attie JN, Blum B. Hyperparathyroidism first suspected through a giant-cell epulis: Report of a case. Oral Surg Oral Med Oral Pathol 1960;13:482-493.

26. Gurumurthy K, Solomon M, Butt KM, Gelfman W, Moel DI. Maxillary brown tumor caused by secondary hyperparathyroidism in an infant. $J$ Pediatr 1982;100:245-247.

27. Weiss RR, Schoeneman MJ, Primack W, Rozycki D, Bennett B, Greifer I. Maxillary brown tumor of secondary hyperparathyroidism in a hemodialysis patient. JAMA 1980;243:1929-1930. 